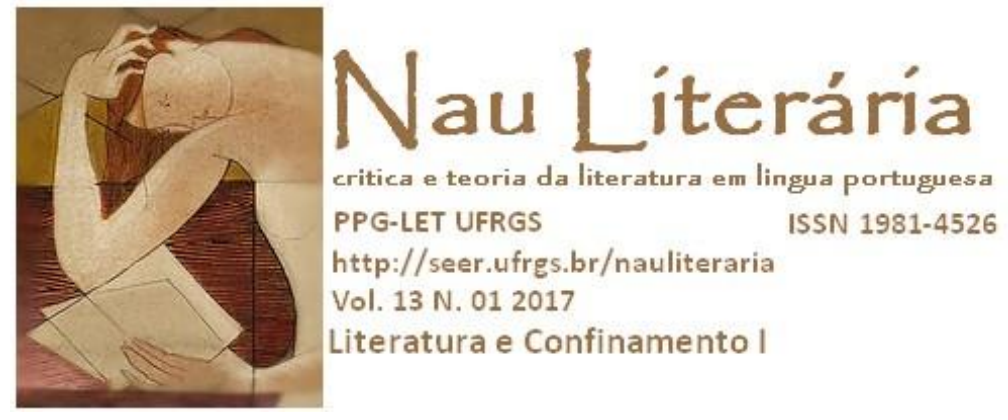

\title{
A prisão da moralidade em Louco do Cati
}

\author{
Jonas Kunzler Moreira Dornelles
}

\begin{abstract}
Resumo: Dyonélio Machado produziu O Louco do Cati a partir de suas experiências no cárcere, numa espécie de sublimação de seu trauma. Ao utilizar seu conhecimento pioneiro de psicanálise, logrou produzir uma contribuição crítica, dentro da tradição literária de obras sobre confinamento, ainda não integralmente avaliada. Situando seu personagem para "além do bem e do mal", Dyonélio pode ter denunciado não só as repressões físicas, mas também as prisões neuróticas presentes em nossa cultura. O quanto essa obra ainda tem algo a nos dizer? O que ecoa da psiquê torturada de seu personagem em nossas subjetividades contemporâneas? O artigo buscará tecer uma interpretação a partir de referenciais da Psicanálise, revitalizando a compreensão a respeito dessa obra-prima de Dyonélio Machado.
\end{abstract}

Palavras-chave: Dyonélio Machado; O Louco do Cati; Literatura no cárcere; Confinamento; Literatura Brasileira.

\begin{abstract}
Dyonélio Machado wrote $O$ Louco do Cati from his experiences in prison trying to sublimate his trauma. By using his pioneering knowledge in psychoanalysis he was able to produce a critical contribution, which was not fully evaluated within the literary tradition of works about confinement. Situating his character "beyond good and evil", Dyonélio might have denounced not only the physical repressions, but also neurotic prisons that are alive in our culture. How much this work still has something to say to us? Which echoes, coming from the character's tortured psyche, our contemporary subjectivities have heard? The article will seek to interpret this work using references from Psychoanalysis, revitalizing our understanding about Dyonélio Machado's masterpiece.
\end{abstract}

Keywords: Dyonélio Machado; O Louco do Cati; Literature about prisons; Warlike morality; Brazilian Literature.

Produzido a partir da experiência de Dyonélio Machado como preso político às vésperas do Estado Novo, O Louco do Cati (2003) revela um particular aprofundamento das narrativas literárias com tema de confinamento produzidas até 1942, ano de seu lançamento. Escrita a partir do ato rememorativo de suas experiências no cárcere, esse autor, algo leitor enciclopédico que era Dyonélio, retomará em sua obra um diálogo que ecoa a longínqua tradição de escritos sobre os suplícios subterrâneos do confinamento, acrescentando sua própria particularidade.

Dyonélio possuía um espírito de pesquisa que está bem documentado em suas 
entrevistas e pequenas reflexões ensaísticas, como em $O$ Cheiro de Coisa Viva (1995). Sua investigação particular sobre a temática do confinamento se inicia na ficção com $O$ Louco do Cati, passa por Desolação (1944), Passos Perdidos (1946) e Nuanças (1981) ${ }^{1}$ culminando no ciclo de produção seguinte ${ }^{2}$, em que o escritor revisou seu grego e seu latim para buscar referências sobre o tema na Antiguidade Clássica. São desse ciclo as obras Deuses Econômicos (1966), Sol Subterrâneo (1981) e Prodígios (1980).

Desprezando as exigências literárias do mercado editorial, que gostaria de ver a reprodução de um novo Os Ratos (1935), Dyonélio logrou afinal produzir uma espécie de genealogia da moral das opressões de nossos tempos, nessa série de obras que se situam sob a égide da repressão do Império Romano de Nero, em que o minucioso resgate do passado desvela a origem dos fenômenos repressivos no contexto presente do leitor. Como se Dyonélio nos pusesse numa máquina do tempo e nos levasse até os primórdios de nossa civilização latina e cristã, o autor nos mostra que não há nada de muito novo sob o sol.

De origens positivistas, Dyonélio possuía já em 1923 uma formação humanista clássica, a que se somaria posteriormente sua predileção por Freud e Marx. Sua primeira obra, Política Contemporânea (1923) já revelava fina hermenêutica, num profundo conhecimento dos destinos políticos e sociais do país. Sua primeira obra de ficção, o ainda pouquíssimo lido Um Pobre Homem (1927), revelaria um autor situado no núcleo dos dilemas contemporâneos, trabalhando com temas como o conflito entre o arcaico e o moderno e questões sobre História e verdade, o que fez com que esse livro de contos fosse considerado pioneiro da moderna ficção urbana brasileira, segundo Erico Verissimo (RAABE, 2014 apud MACHADO, 2014, p. 220).

Mas foi em O Louco do Cati (1942) que Dyonélio primeiro incorporou o seu conhecimento de psicanálise para desenvolver uma compreensão, em certo sentido revolucionária, dos processos de aviltamento do ser humano, além de uma denúncia da psiquê e das moralidades de nossa cultura. Como já vimos, essa estratégia irá se desenvolver em seus próximos livros, mas, para o espaço deste artigo, irei destacar elementos desse momento inicial, buscando iluminar as contribuições de suas inovações técnicas.

Ditando a obra de seu leito a familiares e amigos, enquanto se recuperava de uma crise cardíaca (possivelmente causada pelo trauma do encarceramento), entre remédios e eletrocardiogramas, o escritor e médico utilizou o relato ficcional como um recurso terapêutico. Essa, que é talvez uma das únicas obras ditadas da literatura brasileira, surgiu de

\footnotetext{
${ }^{1}$ Chamada tetralogia da opressão e liberdade por Grawunder (1994).

${ }^{2} \mathrm{Na}$ chamada trilogia da libertação por Bosi (1980).
} 
uma sublimação estratégica para o restabelecimento da saúde mental de seu autor. Ao reconstruir de sua experiência do cárcere os personagens e cenários que haviam ficado "presos" em sua memória por conta do trauma, O Louco do Cati revela não só uma prisão física, como também define os labirintos de uma espécie de prisão psicológica, como poucos livros ousaram representar.

Segundo o autor, "O Louco do Cati descreve uma cadeia política, mas diferente do que a preocupação política da época (esquerda e direita) estava acostumada. Naquele tempo, nem blague se podia fazer - e eu fiz blague de uma cadeia" (MACHADO, 1995, p. 30). Dyonélio realiza a sublimação dessa "cadeia política diferente" numa obra que acontece como uma "blague de presídio", respondendo, assim, com uma bravata à consciência moral que permitiu a legitimação da tortura fascista. Esse "chiste político", como poderíamos dizer, permanece como um golpe de ironia histórica frente à estupidez dos governantes de um povo, capazes de prender um pensador do quilate de Dyonélio. Seria como o caso da morte de Sócrates rememorada por Platão. O julgamento mal explicado, do considerado "pai da Filosofia", entra para a História como mancha que envergonha a memória da polis.

Poderíamos situar a produção ficcional de Dyonélio entre as obras da tradição de escritos do cárcere, como Recordações da Casa dos Mortos de Dostoievski (2006), O Conde de Monte Cristo de Alexandre Dumas (2008), ou ainda os diálogos socráticos como Críton, em que Platão (2009) registrou as opiniões de Sócrates sobre sua própria condenação. Seguramente, marcamos com esses livros a tradição em que figura a contribuição inovadora de $O$ Louco do Cati e o ciclo de obras de Dyonélio que já citamos.

Essas trazem representações do cárcere e da posição do sujeito confinado que poderiam antecipar e se refletir nos calabouços da repressão getulista, iluminando certas permanências milenares, "medievais", na prisão do século XX. Este trabalho seria especialmente importante ao estudar a série de livros da chamada trilogia da libertação, colocando em paralelo a prisão romana de Sol Subterrâneo com os diversos "Carandirus" brasileiros. Para o espaço deste artigo, apenas gostaríamos de apontar esse paralelo, pois afinal aquelas eram obras que Dyonélio certamente devia conhecer (ver MACHADO, 1995, p. 46).

Utilizando-se de todo seu conhecimento do vocabulário e da técnica freudianos para penetrar nas profundezas do que nos constitui enquanto sujeitos, a contribuição de $O$ Louco do Cati será sua crítica radical sobre a subjetividade do povo gaúcho e brasileiro, e o conflito do herói situado numa perspectiva amoral. Foi ao adicionar a visão psicanalítica na tradição de ficção sobre confinamento, que Dyonélio foi um passo além das possibilidades anteriores. 
Vejamos como se constituiu essa crítica a partir dos elementos da obra.

\section{Aventura no cativeiro}

O Louco do Cati narra a peregrinação de um personagem que no livro fica conhecido por apelidos como "seu Cati", Louco do Cati ou variações entre Louco e Cati, mostrando sua trajetória num movimento que se apresenta como uma elipse de fuga seguida de retorno, tendo como vértice do movimento o cenário de origem de suas memórias traumáticas. A obra inicia com essa personagem que irá acompanhar um grupo de "veranistas" de fim de semana, que irão de Porto Alegre ao litoral sul rio-grandense, e de lá (já com apenas outro membro do grupo, Norberto) vão juntos até a fronteira com Santa Catarina, onde ambos acabam sendo detidos pela polícia getulista.

Sua ida até o presídio central carioca e retorno até a fronteira do Rio Grande do Sul aparentemente também poderia se constituir como seu processo de readaptação na sociedade, já que o protagonista vai passando a esboçar pouco a pouco mais reações, como se estivesse em processo de ressocialização pós-detenção. O livro culmina na cena final de uma catarse, em que o personagem irá reencontrar as ruínas do quartel do Cati, cenário originário do inferno de sua subjetividade.

É curioso destacar que o livro carregue o subtítulo de "Aventura", o que, na tradição de romances medievais de cavalaria, representava não só o relato dos grandes feitos maravilhosos, das "aventuras", mas também um apanhado de pequenas narrativas cotidianas e triviais, como que pequenos retratos de costumes e hábitos dos heróis "romanescos". O livro também foi definido por Dyonélio, em uma entrevista, como um "romance-revista": "[...] uma peça de teatro, com quadros de música e dança, com anedotas, alegorias, sketches, etc., na qual se criticam os fatos mais em evidência da época" (MACHADO, 1995, p. 30).

O livro seria simultaneamente um romance de aventuras cavalheiresco e espécie de vaudeville burlesco do Brasil da época, o personagem Louco sendo o herói que passeia "em revista" por entre costumes e cenários de sua época. E não esqueçamos, poderia ser também aquele "chiste político" perante a estupidez nacional, que ignorantemente detinha seus maiores pensadores acreditando que a História não se lembraria de sua sujeira.

Ao adentrarmos na enumeração de ocorrências da obra, veremos que temos quase um antirromance: o protagonista está mais para anti-herói, em muitas cenas apático e alienado, num curso de acontecimentos que parece mais um conjunto de não acontecimentos, de expectativas suspensas e não realizadas. O livro inclusive foi muito criticado à época por essa aparente falta de direcionamento de seu aspecto formal, tendo sido acusado de mal-acabado e 
confuso por um lado, ou ao contrário, sendo reconhecido no parentesco com gêneros literários exóticos, como o romance surrealista, o nouveau roman francês ou o teatro do absurdo de Beckett.

Poderíamos fazer pelo menos uma sugestão para pensar o sentido estrutural, aquilo que motivou o projeto formal desse livro, evitando recair em uma crítica "impressionista". Essa leitura se faria na relação de Dyonélio, médico psiquiatra, com a obra de Sigmund Freud, da qual o autor foi um dos pioneiros da divulgação no Brasil. Ao utilizarmos a obra do pai da psicanálise, encontramos uma ótima chave hermenêutica, que ajudará a esclarecer alguns dos mistérios ainda hoje presentes no livro. Retomemos alguns elementos psicanalíticos que poderiam contribuir nesse sentido.

\section{Revisitando Freud}

Em Totem e Tabu (1987), Freud desenvolve a ideia de uma gênese da lei e da organização social humana, das restrições da moral e da religião, com base em uma hipotética rebelião filial arcaica. Esta hipótese surge predominantemente do diálogo de Freud com a obra de Charles Darwin e a antropologia de James Frazer. Freud imagina um cenário originário, onde um violento "pai primevo" domina todo o bando de primatas, possuindo todos os bens e mulheres do bando para si. Os filhos o temiam e o invejavam, ao mesmo tempo em que o tinham como modelo ideal, em seu comportamento agressivo, possessivo e egoísta.

A Lei e a Cultura, as chamadas realizações da moralidade, teriam sua emergência histórica quando, após sofrerem diversas violências e exclusões, esses filhos se reúnem e assassinam o "pai primevo". Tendo se livrado da ameaça exterior do chefe do bando, eis que surge um sentimento de culpa entre o grupo, significado em um ato que até então não era visto como culpável quando praticado pelo pai. A Lei passaria então da agressividade exterior para a interiorização subjetiva da neurose na "culpa", no superego e na consciência moral.

Os filhos/irmãos arcaicos, temendo possuírem o mesmo destino fatal de seu pai, acabam renunciando às suas posições de poder exterior, subjetivando a lei e criando assim a moral e os tabus, o que recria de certa forma a autoridade original do "pai primevo" dentro dessa nova etapa da sociedade. Assim, poderíamos dizer que o primeiro "Direito", a primeira "Lei" da humanidade, surgiria a partir de um assassinato, que se transfigura em seguida numa renúncia ao instinto. Seria uma espécie de reencarnação fantasmática da autoridade paterna, numa versão primitiva do complexo de Édipo, que renova a autoridade do patriarca após a morte, sob a forma de uma preservação "civilizatória" do conjunto social que põe fim à guerra fratricida. 
Em outra obra de Freud, Mal-Estar na Civilização (1996), teremos a ideia da Cultura como tentativa de arbitrar relações humanas, instaurando-se uma hierarquia vertical de poder, que põe a força da nação contra o poder coletivo, e esse coletivo contra a força do poder individual. Esse sentimento hierárquico de civilização se impõe contra a agressividade inata do homem, contra o instinto de agressão e sobrevivência animal de um estado de Natureza quase darwiniano, digamos.

Essa hierarquia de poder se direciona contra o "Homem lobo do homem" de Hobbes, mas também produz limitações frente à livre vazão das pulsões e vontades dos sujeitos. No início, o processo civilizatório é bom, pois tem como objetivo unir as pessoas e parte das pulsões de Eros, o princípio agregador da Natureza. No entanto, a agressividade contida pela disciplina acabaria se desafogando em rejeições e opressões internas, se voltando contra a psiquê do próprio sujeito das pulsões (naquilo que Freud chama de superego, ou supereu), criando torturas autoinfligidas, que aplicam a agressão, antes objetivada em ameaças exteriores, contra o interior impalpável e subjetivo do indivíduo.

Esse doloroso processo de subjetivação traumática é o processo gerador de neuroses, por meio das quais alguém adquire seu caráter "civilizado". O chamado mal da civilização surge como necessidade frente à "guerra de todos contra todos" da hipótese hobbesiana do "estado de natureza". É revelador que muito deste processo "pedagógico", gerador de neuroses, não seja visto como "traumático", mas apenas uma etapa no processo de "se tornar gente" (a compulsão do Princípio de Realidade freudiano, frente à satisfação imediata do desejo, em Além do Princípio do Prazer (FREUD, 1996)).

Os fenômenos de agressões aparentes, que deixam marcas físicas, são facilmente qualificados como "traumatizantes", mas o processo invisível do desenvolvimento do indivíduo neurótico, em geral, não é qualificado assim. Lembremo-nos de quão difíceis são os debates de condenações por "abuso moral" até o presente momento, ou pensemos na dificuldade de estabelecer uma "régua ética" objetiva, que pudesse se aplicar como critério universal para relações privadas, como os limites em decibéis no tom de voz que os pais podem usar para exercer a educação dos filhos. É também para buscar outros critérios analíticos, em um campo de estudo pouco determinável como o da psiquê, que a Psicanálise de Freud buscou desenvolver-se, conquistando um vocabulário próprio que pode dar conta dessas profundezas subjetivas, que a consciência apenas tangencialmente poderia acessar.

Serão justamente aquelas feridas invisíveis que, criando a subjetividade neurótica, nos serão ofertadas pela moralidade, ao preço da sublimação das pulsões. Nossa felicidade selvagem da infância é castrada, "civilizada", domesticada, para assim ganhar o direito de 
pequenas alegrias reconhecidas pela sociedade. $\mathrm{O}$ mal-estar da civilização surge justamente porque, sob esta condição de civilizados, raramente experimentaremos a mesma intensidade de satisfação das pulsões livres que tínhamos no estado selvagem anterior.

Se desenvolvermos nossa reflexão voltando até algumas sugestões nietzschianas, que influenciaram Freud em suas reflexões, poderemos nos situar no coração desse dilema que gostaria de chamar de "prisão da moralidade". Em obras como a Genealogia da Moral (1999), Nietzsche buscou criticar a consciência moral, a culpa, como reflexos de uma cultura em estado de decadência e definhamento. A origem do que ele chama de "preconceitos morais" (o pré-conceito de que o homem tenha uma natureza moral) é reflexo da dominação de um grupo sobre outro.

A culpa poderia ser a força que os fracos exercem sobre os fortes. A moral poderia ser uma forma de escravidão do espírito. A consciência, quem sabe, poderia ser a doença (neurose), não a saúde (mais próxima da liberdade animal). O diálogo entre Freud e Nietzsche já foi largamente desenvolvido, como apontam Viaro e Valore (2012), em seu artigo sobre a correlação das obras de ambos.

Se podemos suspeitar, com Derrida, de uma herança judaico-cristã na psicanálise (a “questão judaica", que atravessa a discussão freudiana em Mal de Arquivo (DERRIDA, 2001, p. 9), podemos pensar também em algo como um Nietzsche contra Freud. Como encontrar a saúde da subjetividade em meio aos elementos neuróticos da cultura e ao mesmo tempo impedir a "guerra de todos contra todos"? Eis o "labirinto da moral" em que nós, reflexivos leitores do livro, nos vemos metidos. Acredito que O Louco do Cati afinal pode ser visto como uma representação desse dilema.

\section{O herói em ação}

Ao resgatarmos certas concepções freudianas, das quais Dyonélio estava bastante a par devido à sua formação psicanalítica, buscamos indicar um caminho para análise de um caráter pouco explorado de sua personagem. Percebemos que é possível inferir, a partir da textualidade da obra, que o personagem Louco sem dúvida sofre de alguma forma de distúrbio pós-traumático, a partir de seus ataques histéricos. Além disso, se o Louco procura tão obsessivamente o Cati, talvez pudéssemos identificar um desejo recalcado preservado em seu inconsciente: “[Louco] — Que coisas, mãe? [a mãe responde] — Cala a boca: o Cati!" (MACHADO, 2003, p. 34).

Assim, podemos suspeitar que o Cati ocupou o inconsciente do Louco (como na visão aparentemente empática com os tenentes degoladores, que no quartel estavam indo degolar 
figuras maltrapilhas (Idem, ibidem)). Em outras palavras: podemos pensar que o Louco não só teria sido "vítima" das torturas do Cati, como talvez houvesse participado de alguma maneira do Cati, atacando ou pondo-se contra o quartel. E se o trauma que carrega fosse não de torturas recebidas, mas de memórias abomináveis por ações cometidas? Ou de censura a essas delinquências?

Nessa interpretação, o Louco do Cati possui uma dimensão cruel e agressiva de excombatente, que teria dado vazão ao seu interesse pelo Cati. Supomos que pode até ter chegado a degolar pessoas, já que a degola era a praxe cotidiana do quartel, mas também entre aqueles que se opunham a ele ${ }^{3}$. As degolas ocorreram como prática de humilhação, de vendeta (e sem dúvida como prática militar) até a chegada de Getúlio Vargas ao poder, quando passaram a ser proibidas. Houve defensores da degola como método de impor a ordem que tiveram que ser admoestados e punidos após este período (D’AVILA, 2012, p. 120).

Todo esse cenário teria ocorrido antes de o personagem entrar em cena, em estado póstraumático, no início do livro. A obra fornece indícios para essas sugestões por via dos fragmentos de memória que podemos coletar ao longo do livro. Essa interpretação inovadora que quero adotar, do caráter do personagem como um ex-combatente, ganha respaldo na obra se estivermos atentos à postura de seu protagonista em diversos trechos:

O passo de Norberto era mais firme, quase militar. Mas o trancão do companheiro, o seu trancão de maluco, vinha ele observando, que coisa, (está vendo?) que coisa mais indicada praquele [sic] gênero de viagem! A constatação deixou-o pensativo. (MACHADO, 2003, p. 61).

Ela, sentada à sua frente, via-o na sua poltrona, numa posição que era um "triunfo" daquele pessoal do navio. Pelo menos, a nuca do companheiro já sentava com o resto do corpo. [...] Ora! ... ela está encantada com esse... maluco. (MACHADO, 2003, p. 182).

O Louco do Cati é descrito por vezes com o "focinho no ar, procurando o sentido daquela tarefa", em que seu pescoço tenso "se movimenta interrogando" (MACHADO, 2003, p. $15,18,27,81)$. Seu queixo erguido, sua postura algo retesada em todas as cenas, sua postura de triunfo em relação ao pessoal do navio, seu trancão marcial... Todos são elementos que parecem refletir um rigor análogo à postura militar, ainda que não integralmente disciplinada em posições habituais de quartel (a posição de "sentido", de "descansar" etc.).

São diversas as cenas em que vemos o Louco participando e mesmo falando (MACHADO, 2003, p. 20, 37, por exemplo), o que desfavorece certas leituras da obra, que

\footnotetext{
${ }^{3}$ Sobre histórico de degolas no Rio Grande do Sul, ver Degolas e Degoladores (D’AVILA, 2012). Ver também possível memória do Louco amolando uma faca (MACHADO, 2003, p. 26).
} 
constroem numa suposta mudez ou passividade do protagonista sua interpretação. Hoje já sabemos que a crítica de Moisés Vellinho foi a primeira a desabonar violentamente o livro, afirmando que "O personagem central do livro, o louco, cujo nome é sonegado ao leitor sem qualquer motivo apreensível, nada faz, nada diz, não sugere nada.” (VELLINHO, 1960, p. 77). De maneira infeliz, essa crítica se perpetuou até os dias de hoje, vez que outra sendo reproduzida em resenhas ligeiras.

Há cenas em que a personagem quase arranja uma "namoradinha" (idem, p. 163, 176), e na última parte do livro há inclusive, para nossa surpresa, o Louco do Cati conversando tranquilamente com um coronel e um comandante, justamente os sujeitos que mais poderiam lhe trazer dolorosas lembranças de um trauma das torturas do quartel do Cati (idem, p. 229, 239, 248). No entanto, o Louco está ali em cena com eles, fazendo perguntas numa interação corriqueira. O que mudou do início ao fim do livro parece ser que nas últimas cenas o Louco está bem vestido e alimentado, agindo como um sujeito muito diferente da figura anacrônica que surge na cena inicial, alimentando-se de pedaços de carne sujos.

Além disso, encontramos no livro trechos da memória do Louco, que são representativos de sua personalidade, gerando discordância com interpretações que seguem a linha de Moisés Vellinho, a saber, da personagem como figura descaracterizada. Trata-se de alguns trechos destacados na substância do texto, e que, analiticamente, parecem se constituir como reminiscências de sua vida anterior. São parágrafos, portanto, dignos de serem tomados em uma seleção à parte, por estarem todos eles destacados no início e ao fím com reticências. Estes trechos se encontram nas páginas 20, 25, 26, 29, 33, 34 da primeira parte do livro (MACHADO, 2003), e só retornarão com a mesma força evocativa ao final da obra, no momento de desfecho catártico da narrativa, na página 254.

No primeiro desses fragmentos de memória, temos o menino-Cati (chamemos assim para aproveitar a outra parte de seu apelido, já que a esta altura ainda não devia ser o "Louco") que se despede da mãe, embarcando em uma diligência com dois passageiros bondosos, caras escanhoadas, distintas. Algumas memórias de estradas e viagens enquanto criança, e então, imagens de uma degola por ocorrer (MACHADO, 2003, p. 29). Na próxima memória, vemos o menino-Cati quase presenciando outra cena de degola, interrogando sua mãe sobre o que estava acontecendo, ao que sua mãe o manda ficar quieto, pela segunda vez no livro. (MACHADO, 2003, p. 33-34). Destaquem-se estes silenciamentos e repressões maternos, dos quais poderíamos deduzir, freudianamente, que se gestava o recalcamento neurótico de sua pulsão reprimida-desejada. 
Na memória seguinte, o menino-Cati e seus amigos testemunham a chegada de "índios maltrapilhos" sobreviventes de um grande grupo de degolados. O menino-Cati vê passando próximo a si um dos grandes Tenentes do Cati, ouvindo dizer que ele havia tido de trocar seu dólmã, pois o que vestia havia se ensopado de sangue no calor das degolas. O menino, então, observa suas feições excessivamente pálidas (MACHADO, 2003, p. 34). Por fim, há uma memória de um motim entre os oficiais, "os reflexos metálicos de botões dourados sobre dólmãs negros", um entrechocar das espadas, e a lembrança do menino-Cati que, ao ouvir essa narrativa, "só via caras pálidas, fantásticas, em uniformes negros, lendários" (MACHADO, 2003, p. 34).

A narrativa do livro transcorre sem nenhum outro desses parágrafos em destaque, iniciados com reticências. Apenas ao final do livro ele ressurge, no trecho a seguir, meio camuflado entre a visão epifânica do Louco encontrando as ruínas do Cati. Notem-se as reticências indicativas, características dessas sugeridas reminiscências, em que Dyonélio parece querer revelar o inconsciente recalcado subindo à consciência:

\footnotetext{
...Quando saía, à noite, de casa, sem ninguém ver, na figura dum cachorro, - não era mais um homem: tinha virado um lobisomem. Comia imundícies, em todos os monturos... Tão nojento era, tão negro por dentro (e tanto empenho tinha em se tornar cada vez mais negro, para aquela gira de maldade), que não podia comer outra coisa. No outro dia, sabia-se que aquele homem estranho era o lobisomem, por que se punha a vomitar tudo aquilo. Limpava-se, para passar a semana...

Uma vez esse "homem" se casou, sem a moça saber quem ele era. Numa sexta-feira, de noite, a mulher, vestindo um vestido de baeta encarnada, foi atacada por um cachorrão preto, quando saía do pátio. Os dentes do animal e os seus olhos brilhavam no escuro. Ela se defendia. $\mathrm{O}$ cachorrão (o lobisomem) quase despiu-a, a dentadas; a sua saia de baeta vermelha ficou toda em tiras. A mulher porém conseguiu fugir para dentro de casa. Trancou-se. Só abriu para o marido, tarde da noite. Ele vinha cansado (e o olhar negro). Dormiu. Mas no meio da noite, a mulher sentou na cama, erguida por um arrepio, como uma mola; descobrira uma coisa horrível! Entre seus dentes, enxergava os fiapos de sua baeta encarnada. (MACHADO, 2003, p. 254)
}

Tais trechos reticentes, em seu conjunto, são indícios reveladores desta subjetividade traumática, que carregava dentro de si uma matéria inconsciente em que a pulsão de morte agitava-se. O agora jovem-Louco teria cultivado e carregado compulsivamente algo sinistro em seu interior, tanto empenho tinha em se tornar cada vez mais negro, para aquela gira de maldade, "tão negro por dentro". É a partir dessa sugestão, e ao situar o enredo dentro da História Regional, que poderíamos perguntar: teria o jovem-Louco participado do levante de 1923, que veio algumas décadas depois, como rescaldo de 1893 (em que também ocorriam degolas)? Ou participado do golpe getulista de 1930, a partir do qual, ao menos oficialmente, se encerram as degolas como método militar (D’AVILA, 2012, p. 120)? Ou teria participado 
de ambas? Algum combatente poderia dar livre vazão ao seu desejo de degola, aproveitando das liberdades da Guerra, mas após a proibição dessas práticas e do fim das disputas em 1930, teria sido reprimido e lançado ao ostracismo social como delinquente.

Se pensarmos que as primeiras memórias do menino-Louco revelam uma testemunha do Cati pelos dias da Revolução de 1893, onde ele presencia cenas de degola junto à sua mãe, poderíamos deduzir, pela linguagem do diálogo e com alguma folga de definição entre os critérios etários, que ele deveria ter entre três e doze anos (pois na pergunta sobre o Cati para a mãe, ela responde: “[...] um menino não fala nessas coisas” (MACHADO, 2003, p. 34). Além disso, sua pergunta parece mais vinda de criança do que de adolescente).

Sabemos que $O$ Louco do Cati se passa nos meses finais de 1935, já que Desolação (1944), a obra que continua a história imediatamente após o livro, é explícita na determinação temporal diegética. Essa obra, que mostra a viagem de volta dos "veranistas" da parte inicial de $O$ Louco do Cati, passar-se-á nas semanas seguintes à primeira narrativa, e tem demarcada a data dos últimos meses de 1935, quando Getúlio Vargas começa a preparar o Estado policialesco que viria a se tornar o Estado Novo em 1937.

Podemos, assim, buscar determinar uma idade aproximada do Louco na chegada da cena inicial. Com alguma folga para mais ou para menos, poderíamos dizer que seria algo entre quarenta e cinquenta anos. No intervalo de tempo que a obra não descreve, um curioso pelo modus operandi das disputas militares gaúchas poderia ter tido diversos momentos de liberdade para provar seu gosto, em uma das (praticamente) guerras civis que vão de 1893 até 1930. Podemos concluir afirmativamente, no entanto, apenas que algo por fim lhe aconteceu, e que mais tarde, nos momentos mais próximos à sua aparição no livro, restou apenas um vago "homem-lobo", já delinquente, atacando uma mulher à noite, rasgando suas roupas a dentadas (as memórias finais do livro).

Seria interessante fazer um comparativo com o estudo de caso da neurose infantil em O Homem dos Lobos (FREUD, 2010), no qual Freud conta etapas de análise de um paciente que supostamente teria sido curado pela psicanálise (caso cuja controvérsia se estende até a morte do paciente nos anos 1970). Mas prefiro partir da constatação de certa epidemia classificatória, uma proliferação que leva à incerteza quanto a um diagnóstico definitivo (CAMARGO; SANTOS, 2012). Prefiro, portanto, não deduzir diagnósticos de neuroses, psicoses ou perversões a partir da literatura. Gostaria antes de reforçar, por outro lado, a imagem do cachorro, ou lobo domesticado, como a imagem do animal servil e instrumentalizado pelo ser humano para fins de caça e de autodefesa. Aquele que obedece quando dizemos "deita", "rola", "finge de morto" ou "ataca!", "pega!”. Como um servo que 
obedece a um amo, ou como um soldado que obedece a comandos militares...

O Louco do Cati seria esta espécie de animal servil, instrumentalizado para certos propósitos cruéis durante as guerras, como um combatente serve a certa causa. Poderíamos dizer então que $O$ Louco do Cati passa "em revista" os fatos de seu tempo, aproveitando a ambiguidade entre a definição do livro como romance-revista, e o verbo "revistar", típico das ações de segurança policial.

Concluo assim a ideia do Louco como ex-combatente (que poderia ter passado à delinquência), resgatando uma afirmação de Dyonélio no sentido dessa leitura, em que afirma sobre o caráter de seu personagem: "Tudo quanto se vê nessa figura ainda não é bastante para abominá-la. Certa crítica [...] esquece que ele foi menino [...] que viu horrores na infância, a servirem como elemento para um futuro mentecapto" (MACHADO, 1995, p. 29).

Retomemos a ideia de que o livro seria o relato de "aventuras" de um herói cavalheiresco. Quais seriam os valores pelos quais nosso herói cavalheiresco combateria afinal? Quais reinados, quais bandeiras defender? Talvez devêssemos lembrar que o Cati já foi motivo de orgulho nacional, e seu administrador, João Francisco, figura conhecida como a "hiena do Cati", recebeu louros e festejos quando de visita ao Rio de Janeiro, capital federal da época.

Houvera um tempo em que rezava lenda que "[...] a hiena arranca dentes, capa, degola e estupra inimigos, depois manda os soldados montarem acampamento sobre os cadáveres pra se acostumarem, estoicamente, ao cheiro da morte" (SOARES, 2017, p. 105). Se a anedota ficava para lenda, sobravam relatos de frequentes filas de pessoas sendo degoladas em série, alinhadas e abatidas como gado em um matadouro. Se já não bastasse, um "exagero" das tropas do Cati: fizeram um rebelde comer como churrasco a carne assada de seu próprio pai (CAGGIANI, 1997, p. 74).

Quando a coisa chegou ao ponto de “[...] que era impossível deixar no espírito público, por mais tempo, a opinião de que o Rio Grande era governado pelo despotismo que diziam" (idem, p. 107), João Francisco é por fim reabilitado em banquetes cariocas, como "auxiliar poderoso na defesa das Instituições ameaçadas" um "dedicado servidor da República" (idem, p. 105-109). Sua reabilitação é coroada com a do Quartel do Cati, quartel já visto como nobre representante das modernas técnicas de combate à desordem, meramente difamado pela calúnia da oposição.

Não seria o nosso herói alguém como o próprio João Francisco, a "hiena do Cati", alguém que apenas busca eficiência política e militar, mesmo que "desmedidamente", dentro de um realismo político algo maquiavélico? Não poderíamos dizer que os valores do herói 
dizem respeito à eficiência militar a qualquer custo, inclusive por meio da degola, ou seja, o mesmo motivo pelo qual se admirava o Cati à época? Afinal, João Francisco foi reformado como tenente coronel da Brigada Militar", tendo sido reconhecidos em decreto "seus grandes serviços prestados ao Estado" (idem, p. 208), e podemos dizer que o degolador entrou pra História afinal como um herói.

Gostaria de voltar aqui à sugestão de Dyonélio, de sua "blague de cadeia". Imaginemos que uma "blague de presídio" é como uma espécie de blefe político, a ameaça de um inferno maior do que a morte, que a degola, que se ameaça ao grupo adversário como resolução da guerra. A degola vira assim uma metáfora não só para o ato físico, mas para o silenciamento da versão do vencido, para o esquecimento. Uma bravata com que se ameaça aos prováveis perdedores da guerra, com futuras torturas, com ultraje histórico, blefe que se faz aos inimigos que supostamente perderão. Seja uma Sibéria comunista ou uma Guantánamo capitalista, teremos esse espaço de ameaça que os vencedores indicam aos vencidos.

O ponto principal, partindo-se da interpretação do Louco como ex-combatente, não seria atribuir um lado (maragato ou chimango, esquerda ou direita...) como ideal a ser defendido, já que o livro não fornece indícios para tal definição. Mas, indo além, como poderia haver um "lado certo" ou uma justiça para defendermos se - ao pensarmos em uma disputa como a Guerra Civil de 1893, em que irmão mata irmão — ambos os lados utilizam a técnica da degola, sem construir uma medida, criar a Lei, um Direito, a Cultura?

Este período fratricida, em que não se sente culpa, lembra a época arcaica descrita por Freud em Totem e Tabu (1987) quando o pai fantasmático ainda não se perpetuou na moral psíquica. A premissa aqui seria a antiga máxima do "guerra é guerra": para acabarmos com o Cati, faz-se necessário utilizar a mesma técnica que o Cati. Ou, para acabarmos com os barbarismos, só degolando estes degoladores! Estaríamos, assim, num estado mais próximo da Vontade de Potência nietzschiana amoral, em que as forças vulcânicas agem sem repressão da moral cristã (como o Zaratustra, o homem que cria seus valores).

Nesse sentido, faria pouca diferença saber se o impulso do jovem-Cati o levou a servir no Cati (o que se atestaria, entre outros trechos, pela aparente empatia que sente pelo Tenente chimango (MACHADO, 2003, p. 34)), ou se essa pulsão o levou a combater pela causa maragata oposta (o lado dos "revolucionários", os índios maltrapilhos, algo selvagens, descritos nesta cena, que iam morrer no Cati), já que ambos os lados utilizaram-se das

\footnotetext{
${ }^{4}$ Seu efetivo, o $2^{\circ}$ Regimento do Cati, foi incorporado aos brigadianos em 1908, e sua reforma acontece no ano de 1936 (CAGGLIANI, 1997, p. 65, 208).
} 
mesmas técnicas na guerra, sem nenhuma "civilidade".

É pela descrição desse sem saída entre crueldade bélica e civilização que $O$ Louco do Cati asseguraria seu espaço irônico como obra literária, já que não precisamos tomar partido para perceber que todos se situam de um mesmo lado. O personagem Louco passa a primeira parte do livro fugindo do Cati, mas tão logo se vê bem alimentado e vestido, ele volta a procurá-lo para reencontrar a pulsão de morte.

Seria somente vencendo o Cati, conquistando a ameaça do "pai primevo" do Cati, ameaça essa que domina a todos na região, que se poderia chegar à construção da Lei, do Direito. Que, no entanto, surgirá desse crime original, o assassinato, a mesma técnica empregada pelo pai contra os filhos, só que agora visto pelo olhar da culpa, da neurose, da moral. E poderíamos dizer com Nietzche, da diminuição da saúde: "Eu fiz de minha vontade para a saúde, para a vida, minha filosofia [...] eu, o último alemão antipolítico" (NIETZSCHE, 2003, p. 25, 27). Voltamos ao "labirinto moral", ao dilema de tomar partidos. "O Cati era um Subestado. Era um Estado para aquela região. Não raro entrava em conflito com o verdadeiro Estado, e o vencia. Polvo [...] estendia tentáculos, atava, arrastava, triturava. [...] não respeitavam nem as mulheres" (MACHADO, 2003, p. 30).

Gostaria de destacar, por fim, que Dyonélio não estaria assim interessado em defender uma moralidade, "um dos lados" que seria "o mocinho". Não custa lembrar que a família de Dyonélio era de tradição chimanga (TILL, 1995, p. 21) e Dyonélio foi por muito tempo do Partido Republicano Rio-grandense (chimango), antes de se tornar comunista (o que o faria, quem sabe... maragato). (MACHADO, 1995, p. 15) Dyonélio conheceu ambos os lados da disputa, mas não estava interessado em utilizar sua literatura para defender uma ideologia, ou fazer um panfleto de acusação dos culpados por seu trauma de confinamento. "Mas nunca fiz política na ficção. Fiz política nas praças, nas assembleias e fiz política na... polícia.” (MACHADO, 1995, p. 19).

Dyonélio era bastante ciente dos processos históricos das Revoluções, tendo refletido sobre eles no capítulo “Análise Sociológica da Revolução”, de seu primeiro livro, Política Contemporânea (2006). Sabia que "A Revolução Francesa, donde data o mundo moderno, não se operou unicamente pela confluência de forças sãs.” (MACHADO, 2006, p. 34). Guardemos, assim, a ideia de uma condição em que a disputa se faz utilizando as mesmas técnicas, como é o caso daquilo que chamamos de "blague de presídio", ou seja, ameaçar os adversários com o paredão ou com desaparecimentos.

\section{Crítica à moralidade bélica}


Nesse sentido, O Louco do Cati antes revela um processo psíquico paradigmático, realizando algo entre uma genealogia da moral e uma psicanálise de nossa Cultura. Viria ao caso, assim, uma abordagem genealógica nietzschiana já que os valores do herói do livro estariam, digamos, para Além do Bem e do Mal (2002). Nietzsche defende, em seu projeto de transvaloração de todos os valores, um retorno às ancestralidades pré-cristãs frente à moralidade repressora das pulsões. Tal retorno se manifesta, para ele, nos bárbaros germânicos ${ }^{5}$, ou no retorno ao mundo dionisíaco pré-socrático (NIETZSCHE, 1992; 1995). Poderíamos dizer que ele busca refletir sobre uma "subjetividade amoral", que numa figura trágica gera seu próprio valor, baseando em sua própria perspectiva, em sua pulsão ou Vontade de Poder, os valores dignos de serem alcançados.

Em Dyonélio encontraremos parâmetros de uma psiquê assim, para além da moralidade neurotizadora judaico-cristã, nas figuras do gnosticismo algo Renascentista do conto Velho Sanches (MACHADO, 1927), ou, mais evidentemente, no interesse de Evandro por Terapeutas do Egito, pelo cristianismo primitivo algo oriental, pelo paganismo romano ou divergências das divindades oficiais, em Deuses Econômicos (MACHADO, 1966). Acompanhando Onfray em seu Contra-história da Filosofia (2008), podemos pensar nos usos hedonistas, materialistas, de certa tradição anti-idealista, que se opõe historicamente aos valores judaico-cristãos (e também aos platônico-hegelianos).

Os cavaleiros andantes gaúchos, centauros do Pampa, homens livres a cavalo por campos sem fronteiras, com os quais, conforme seus relatos (MACHADO, 1995, p. 94), Dyonélio conviveu em sua infância, serviriam também como fonte exemplar de uma subjetividade despida do conflito da moral, das prisões psíquicas de sua neurose. Podemos pensar a própria noção de infância, quando Dyonélio testemunhou esses homens a cavalo do Sul do Brasil (como também o testemunha o menino-Louco...), como sendo um período liberto de toda "moralidade" (quase puro princípio do prazer, próximo ao sadismo (MACHADO, 1995, p. 92)), lembrando-nos das concepções de infância em Freud.

Evidentemente, dessa forma estaríamos vendo Dyonélio por um viés irônico, que se afasta de uma visão humanista do autor, em sua atuação pública como médico ou deputado. Penso, com segurança, que podemos situar o problema que sua obra tenta revelar pelo viés da saúde. Gaglietti (2007) aponta em Dyonélio o que ele chama de "a medicina como estratégia biopolítica" (idem, p. 111), ao analisar atas de debates parlamentares. Dyonélio seguiria à risca o mandamento de Hipócrates: "Não somente é preciso fazer por si mesmo tudo o que

\footnotetext{
${ }^{5}$ A hipótese de origem do "Estado" sem culpa, em Genealogia da Moral (NIETZSCHE, 1991, p. 53).
} 
convém, mas concorrer também para que o façam os doentes, os circunstantes e as coisas exteriores" (NAVA, 1957, apud GAGLIETTI, 2007, p. 128).

No nível da saúde mental privada, o "vilão da história" poderia ser antes o processo de formação traumática neurotizante da civilização, que impõe a todos, bons e maus, uma disciplina subjetiva que nos forma como "torturadores de nós mesmos" (ao invés, é claro, de "torturadores dos outros"), e depois apaga estes sujeitos da História, esquecendo que foram necessários crimes para se produzir heróis. Estamos num nível de subjetivação anterior à resolução pública de instaurar uma Lei coletiva, que seria a moral. Lembremos que, ao final do livro, quando o Louco do Cati se torna um jovem, ele é despido das tensões de sua educação formativa, que se renova numa fantasia de retorno à infância anterior a qualquer disciplina.

O "herói" que Dyonélio propõe não poderia ser esse bode expiatório, imolado pela "crueldade neurótica" (ou pela "disciplina moral"), que o cria para servir como instrumento eficiente contra o inimigo, veículo ou ferramenta de guerra (um cão de guarda dos valores, ou o assassino que faz o trabalho sujo, por exemplo) de uma moralidade "X", mas depois o descarta, o silencia, por ter-se tornado grotesco, insociável (apenas por ter sido o mais fiel servidor desse valor)? A cena final do livro mostra o Louco do Cati reencontrando o Cati, libertando-se dele, recuperando a sua juventude. Porém, como seria se o quartel do Cati ainda operasse no momento de seu retorno? O Louco viveria em seus arredores, o cercaria, observando, fazendo rondas, vigiando, combatendo? Incorporar-se-ia em seu regimento?

Se pensamos na dialética do "guerra é guerra", de acordo com a qual toda técnica suja é legitimada pela hipótese do Estado de Natureza, chegamos ao núcleo do dilema subjetivo. Gostaria de sugerir aqui que, neste campo, talvez devamos avançar para uma renovação de vocabulário, a partir de Michel Foucault em sua obra Em Defesa da Sociedade (1976). Neste curso, o autor se interroga sobre a legitimidade do modelo de guerra como forma de descrição das relações de poder, propondo um novo viés e uma nova proposta analítica, que servem de renovação das esperanças dentro mal-estar das ideologias.

Resgatando os discursos de políticos de guerra desde a Antiguidade até o Nazismo, Foucault investiga as profundezas da constituição dos sujeitos e suas "sujeições", desenvolvendo um novo vocabulário para o debate. Seu confronto entre as noções de "biopoder" e poder disciplinar, e entre as noções de soberania e dominação busca definitivamente avançar na analítica da moralidade de guerra, mostrando os meandros ideológicos entre público e privado que se justificam sob o "guerra é guerra". O caminho em nível privado, psíquico, seria construir saídas, saberes e higienes médicas, às quais 
recorreríamos enquanto técnicas terapêuticas quando a compulsão-Cati, criadora de "Loucosdo-Cati" aprisionados pela moral, se infiltrasse em nossas subjetividades neurotizadas pela ação política.

Então não é que Dyonélio defenda um dos lados ambíguos do "guerra é guerra", ou alguma moral, e com isso justifique quaisquer fins. "Nada é mais cruel do que a guerra e entretanto ela adquiriu através da História seus foros de legitimidade”. (idem, p. 130). Desse viés, paradoxalmente, Dyonélio poderia ser utilizado como defesa por seus torturadores do Estado Novo, que buscariam “degolar" outras vozes para impor sua versão da História.

Dyonélio sabe que, muito mais que a guerra, o problema da paz é que é o grande desafio a ser trabalhado. (MACHADO, 2006, p. 11). Critiquemos o suspeito uso político, posterior, pragmático, extraliterário, que se faz sobre o discurso da guerra em $O$ Louco do Cati (o personagem como vítima de um dos lados). Inclusive, enquanto deputado marxista, Dyonélio era suficientemente irônico ou conciliador para escapar de visões unilateralistas. Se adotava algum posicionamento moral, era na vida pública, na ação contingente, não numa literatura "moralista".

Se na gênese do livro temos um autor que se sentia "prisioneiro da cama" (MACHADO, 1995, p. 29), que desejava narrar uma "cadeia política diferente da preocupação da época”, definimos em concordância com isso nossa análise da obra, a saber, a aventura deste herói trágico poderia ser, afinal, um "chiste político".

As nossas leis de segurança (inclusive a que me atingiu) tiveram o dom de tirar do vocabulário político a palavra "Não". Imagine-se um indivíduo a quem se mete goela abaixo uma bebida imunda ou envenenada. Não se reconhece o direito de não ingeri-la. Não deve causar nenhuma surpresa se um dia ele vomitar em plena cara de quem lhe deu a beber (MACHADO, 1995, p. 102).

Visto que personifica uma prisão da moralidade em seus limites máximos, colocados contemporaneamente para qualquer lado que se queira saudável, a genialidade de Dyonélio, de forma irônica, sobrevive na História como um monumento à burrice daqueles que o detiveram. É seu vômito saudável da cicuta que lhe deram.

Ele se aproxima assim de Sócrates, como o filósofo justifica sua própria prisão em Críton (PLATÃO, 2009) adotando a moral da época. Ao mostrar mais conhecimento das leis que seus juízes, ele expõe a ignorância profunda daqueles que buscaram condená-lo. Manchou-se de maneira ridícula uma sociedade medíocre que condenou à morte um de seus maiores gênios. Em descompasso com o valor histórico único do condenado, a reflexão de $O$ Louco do Cati debocha assim da pequenez do Estado Novo e de Getúlio, desconhecedores de suas neuroses. 
Nos dias de hoje, enquanto o discurso do "guerra é guerra" se prolifera na sociedade, um círculo compulsivo do Louco do Cati retorna como retrato final da psiquê tanto do lado "esquerdo" quanto "direito". Um resultado e exemplo paradigmático disso, Louco do Cati encarnado, seria o caso de Geraldo Vandré, que tendo sido cruelmente torturado, passa para o lado de seus torturadores militares, justificando a própria tortura com a máxima do "guerra é guerra" (NETO, 2010).

Esperamos que a definição da "prisão moral", que Dyonélio teria tentado descrever, baste para destacar a importância central, ainda não de todo assegurada, dessa obra única da literatura brasileira. É principalmente nos tempos de confusões e brigas que a "direita" e a "esquerda", a saúde e a doença se confundem e parecem assemelhar-se em suas ameaças e blefes, recheadas de "ameaça moral". O "jogar verde pra colher maduro" do medo, as pequenas "lições": "Olha! Vou te mandar pro paredão!", ou o "Vamos prender essa vagabundagem!" são típicos discursos que populistas adotam em tempos de crise, buscando voto rápido.

Não seria a denúncia dessa prisão, desse labirinto, que a proposta psicanalítica de Dyonélio adiciona à tradição de literatura de confinamento? Veríamos assim O Louco do Cati numa importante chave de compreensão (para além do bem e do mal) de nossa psiquê autoritária, chegando à percepção e ao entendimento de si.

Encerremos nossa reflexão aqui, indicando a atualidade do livro. As políticas de segurança do Estado, em um dito período democrático, quando o chamado combate aos "inimigos da ordem" ganha foros de disfarçada legalidade, revelam o que sempre foi prática costumeira. Muitas coisas que são consideradas crimes, voltam a ser defendidas abertamente. Como argumenta Jessé Souza, sobre as heranças coloniais do Brasil:

Matar preto e pobre não é crime desde essa época. As atuais políticas públicas informais de matar pobres e pretos indiscriminadamente efetuadas por todas as polícias do Brasil, por conta do aval implícito ou explícito das classes médias e altas, têm aqui seu começo. (SOUZA, 2017, p. 78).

Segundo o autor, o uso sistemático da polícia como forma de intimidação, repressão e humilhação dos setores da população não é um reflexo da crise da segurança, mas a própria gestão habitual das desigualdades sociais, funcionando de maneira perfeita e eficiente.

Se nos lembrarmos de que a atuação da Brigada Militar é propagandeada em homenagens, sendo motivo de orgulho na publicidade do Governo do Estado, e que esta corporação tem parte substancial de suas origens no quartel do Cati, podemos pensar que a denúncia de Dyonélio, de fato, continua atingindo nosso contexto presente. Dyonélio ficou 
preso mesmo em um quartel da Brigada Militar (MACHADO, 1995, p. 114). O Louco do Cati andaria assim pelas ruas da Porto Alegre atual, denunciando a cada viatura que passa, abundante de pulsão de morte: Isto! Isto é o Cati!!!

Além disso, se pensamos na dinâmica do imperialismo/terrorismo, na qual vemos, por exemplo, os governos norte-americanos adotarem justificativas para invadir ano após ano outros países, de acordo com a qual supostas ameaças terroristas? Em nome da democracia se adotam políticas terroristas, com a desculpa de pôr um fim definitivo ao terrorismo, no velho discurso da "guerra para acabar com todas as guerras". Como impedir esse imperialismo? Já não nos sentimos ficando doentes de uma compulsão sem saída, ficando prisioneiros da cama, na busca de uma solução interna para isto?

Resta-nos então reler a obra e, seguindo o bordão neokantiano, adaptado para nosso autor, repensar os caminhos irônicos deste grande escritor que foi Dyonélio. Voltemos a Dyonélio! Encerro com suas palavras, que devem situar o problema, não pequeno, que nos resta pela frente: “Já para esse tempo, a Paz estava aí, mais assustadora que a própria guerra, a exigir um trabalho inominável por parte dos governos" (MACHADO, 2006. p. 11).

\section{Referências}

BARBOSA, Márcia Helena Saldanha. Dyonelio Machado. Org. Márcia Helena Saldanha Barbosa \& Maria Zenilda Grawunder. Porto Alegre: UE/PORTO ALEGRE, 1995.

D’AVILA, Ney Eduardo Possap. Degola e degoladores no Rio Grande Do Sul (1889-1930). Porto Alegre: Edigal, 2012.

DOSTOIÉVSKI, Fiódor. Recordações da Casa dos Mortos. São Paulo: Nova Alexandria, 2006.

DUMAS, Alexandre. O Conde de Monte Cristo (Volume I). São Paulo: Editora Martin Claret, 2008.

FREUD, Sigmund. História de uma neurose infantil: O Homem dos Lobos. São Paulo: Companhia das Letras, 2010. . Além do princípio de prazer. Rio de Janeiro: Imago, 1996.

Imago, 1996. . O mal-estar na civilização. In: O futuro de uma ilusão. Rio de Janeiro: Totem e tabu. Rio de Janeiro: Imago, 1987.

FOUCAULT, Michel. Em defesa da sociedade: Curso no Collège de France (1975-1976). São Paulo: Martins Fontes, 2000. 
GRAWUNDER, Maria Zenilda. Alegoria na literatura brasileira: a tetralogia 'opressão e liberdade' de Dyonelio Machado. Tese (Doutorado em Letras). Pontifícia Universidade Católica do Rio Grande do Sul, Porto Alegre, 1994.

MACHADO, Dyonélio. O Louco do Cati: (aventura). São Paulo: Editora Planeta do Brasil, 2003.

. O cheiro da coisa viva. Rio de Janeiro: Graphia, 1995.

. Um pobre homem. Porto Alegre: Globo, 1927.

. Deuses econômicos. Rio de Janeiro: Leitura, 1966.

. O pensamento político de Dyonélio Machado. Porto Alegre: Assembleia Legislativa do Estado do Rio Grande do Sul, 2006.

. Proscritos. Porto Alegre: Siglaviva, 2014.

NETO, Geneton Moraes. (GLOBO NEWS - 21/09/10) Geraldo Vandré Especial. Disponível em: <http://g1.globo.com/platb/geneton/2010/09/21/geraldo-vandre-especial-tudo-o-que-ogrande-mudo-da-mpb-disse-na-primeira-gravacao-que-faz-para-uma-tv-depois-de-decadashoje-ele-garantenao-existe-nada-mais-subversivo-do-que-um-subdesenvolvi/>. Acesso em: 20 dez. 2017.

NIETZSCHE, Friedrich. A filosofia na idade trágica dos gregos. Lisboa: Edições 70, 1995.

. Além do Bem e do Mal. São Paulo: Companhia das Letras, 2002.

. Assim falou Zaratustra. São Paulo: Civilização Brasileira, 1977.

. Ecce Homo. Porto Alegre: L\&PM, 2003.

. Genealogia da Moral. São Paulo: Companhia das Letras, 1999.

. O Nascimento da Tragédia. São Paulo: Companhia das Letras, 1992.

ONFRAY, Michel. Contra-história da filosofia - 1: as sabedorias antigas. São Paulo: Martins Fontes, 2008.

PLATÃO. Apologia de Sócrates. Críton. Lisboa: Edições 70, 2009.

SOUZA, Jessé. A elite do atraso: da escravidão à Lava Jato. Rio de Janeiro: Leya, 2017.

SOARES, Jô. O Livro de Jô. São Paulo: Cia das Letras, 2017.

TILL, Rodrigues. Dyonélio Machado. O homem - A Obra. Porto Alegre: ERP Edições, 1995.

VELLINHO, Moisés. Letras da Província. Porto Alegre: Editora Globo, 1960. 
VIARO, Volpato Renee; VALORE, Luciana Albanese. Da moral nietzschiana ao mal-estar freudiano: algumas aproximações e decorrências éticas. Estilo da Clínica, Vol. 17, n. 2, p. 373-395, dez., 2012. 